Nippon Suisan Gakkaishi $\quad$ 81(1), 137 (2015)

\title{
ミニシンポジウム記録＼cjkstart頭足類学の創成一水産学における応用的基礎として一
}

\section{4. ゲノム科学からみた頭足類}

吉田真明 $1,2 \mathrm{a}$

1国立遺伝学研究所生命情報研究センター, 2フロリダ大学ホイットニー海洋生物学研究所

4. Genomic studies of the cephalopods

MASA-AKI YOSHIDA ${ }^{1,2 a}$

${ }^{1}$ Center for Information Biology, National Institute of Genetics, Mishima, Shizuoka 441-8540, Japan, ${ }^{2}$ The Whitney laboratory for Marine Bioscience, University of Florida, St. Augustine, FL 32080, USA

\section{1.はじめに}

ゲノム科学はゲノムプロジェクトと共に発展した分野 で, 生物の設計図であるゲノム DNA を解読することで 重要な生命現象の機構を次々と解明してきた。さらに次 世代シーケンス技術の目覚ましい発達によって, 高速か つ低コストに遺伝子情報が得られるようになりゲノム科 学は大きな転換点を迎えており, 研究室単位でも動物の 全ゲノム解析ができる時代がすぐそこまで来ている。

頭足類がもつ特異な点として, 細胞数と構造の複雑さ で脊椎動物に匹敵する脳神経系が挙げられる。春椎動物 に打けるゲノム研究の結果から, 全ゲノム重複による遺 伝子数の増加が脳進化に寄与したことが示唆されてい る。頭足類ゲノムは一般的に巨大で, ヒトゲノム（約 30 億塩基対）より大きいものが大半である。ここで頭 足類の巨大ゲノムは重複によるのであらうかという疑問 が浮かぶ。しかし頭足類を含む軟体動物はゲノム科学の 潮流から取り残された動物と言ってよく，ここ数年でよ うやくマガキ, アコヤガイ, 拈よびセイヨウカサガイの 3 種の全ゲノム配列が論文として発表され, 軟体動物内 の全ゲノム比較解析が可能となった。本稿では我々のこ れまでの取り組みと現在進行中のゲノムプロジェクトに ついて, 頭足類学に抢けるゲノム科学の先端の取り組み を紹介したい。

2. ヒメイカの部分ゲノム配列決定とゲノムサイズ推定 ヒメイカIdiosepius paradoxus は最も小型な頭足類の
1 種で, 実験室内での飼育と発生の観察が容易なことか ら我々は “モデル頭足類”として用いてきた。この種か らゲノム配列情報を得るため, 部分ゲノム配列決定を行 い $117 \mathrm{Mbp}$ の塩基配列を得た。 ${ }^{11}$ サンプリング率の推定 から，これは全ゲノムの $5.5 \%$ にある量で, ゲノムサ イズが約 21 億塩基対であるとの推定值を得た。これは 頭足類で知られている中で最小であり, 精子 DNA 含量 による実験的な検証からも支持された。またゲノム中の 少なくとも $10 \%$ 以上がマイクロサテライト等の単純繰 り返し配列であることも明らかになった。11

\section{3. ヒメイカの全ゲノム配列プロジェクトと頭足類巨大} 脸の進化仮説

ヒメイカのゲノムサイズが小さいことは遺伝子モデル の推定に有利であるため, 本種を頭足類ゲノム科学のモ デルとして用いるべく, 全ゲノム配列決定に挑戦を始め た。時を同じくして頭足類ゲノムにおける国際共同研究 がスタートし, オウムガイを含めた 10 種の頭足類のゲ ノム解析が進行中である (The Cephalopod sequence consortium: http://cephseq.org)。ヒメイカと他の軟体 動物の間で比較ゲノム解析を行ったが，全ゲノムレベル の重複の痕跡は見られなかった。これはホックス遺伝子 群を 1 セットしか持たないこととも一致する。 ${ }^{2)}$ 一方で 神経接着分子やシナプス足場タンパクに部分的な遺伝子 重複が見られることを見出した。これらの遺伝子は神経 細胞の興奮やシナプス形成に働くことが知られ，多様な 機能をもつ神経細胞を生み出すのに関わっている可能性 がある。今後は, 神経機能と結びつける分子・神経生物 学研究や, 行動や記憶など頭足類の特性を活かしたゲノ 么研究の発展が期待される。

\section{文献}

1) Yoshida MA, Ishikura $Y$, Moritaki T, Shoguchi E, Shimizu KK, Sese J, Ogura A. Genome structure analysis of molluscs revealed whole genome duplication and lineage specific repeat variation. Gene 2011; 483: 63-71.

2) Pernice M, Deutsch JS, Andouche A, Boucher-Rodoni R, Bonnaud L. Unexpected variation of Hox genes' homeodomains in cephalopods. Mol. Phylogenet. Evol. 2006; 40: 872-879.

a 日本学術振興会特別研究員 PD (JSPS postdoctoral research fellow) 